\title{
Genetic differentiation among natural populations of the Nile tilapia Oreochromis niloticus (Teleostei, Cichlidae)
}

\author{
JEAN FRANÇOIS AGNÈSE* †t, BÉATRICE ADÉPO-GOURĖNE + , EDDIE KOFFI \\ ABBAN§ \& YVES FERMONT \\ + CNRS, UPR 9060, Université Montpellier II, F34095 Montpellier Cedex 5, France, $\ddagger$ Centre de Recherches \\ Océanologiques, ORSTOM, BP V18, Abidjan, Côte d'lvoire, \$lnstitute of Aquatic Biology, PO Box 38, Achimota, \\ Ghana and 1 Museum National d'Histoire Naturelle de Paris, 43 rue Cuvier, 75731, Paris Cedex 05, France
}

\begin{abstract}
We analysed the genetic differentiation among 17 natural populations of the Nile tilapia Oreochromis niloticus (Linnaeus, 1758) using allozymes and restriction fragment length polymorphism (RFLP) of mitochondrial DNA (mtDNA). The populations studied, from the River Senegal to Lake Tana and from Lake Manzalla to Lake Baringo, represent all subspecies which have been previously described. Sixteen variable nuclear loci showed that these populations can be clustered in three groups: (1) West African populations (Senegal, Niger, Volta and Chad drainages), (2) Ethiopian Rift Valley populations (Lakes Awasa, Ziway, Koka and the Awash River) and (3) Nile drainage (Manzalla, Cairo, Lake Edward) and Kenyan Rift Valley populations (Lakes Turkana, Baringo and River Suguta). Nine different mtDNA haplotypes were found in the RFLP analysis of a $1 \mathrm{~kb}$ portion of the D-loop region. The network obtained showed that there are three geographically distinct groups; all West African populations and $O$. aureus are clustered, the two Ethiopian Rift Valley populations are distinct and between these two groups are the Kenyan and Ugandan Rift Valley populations. Nile populations show affinities both with West African populations and with specimens from Lakes Tana and Turkana. Taxonomic and biogeographical implications of these results are discussed.
\end{abstract}

Keywords: allozymes, cichlid, fish, mtDNA, PCR, population genetics.

\section{Introduction}

Cichlid fishes of the genera Tilapia, Sarotherodon and Oreochromis are commonly named tilapias. They are of great economic interest, either in fisheries or in aquaculture. Among all the species, the Nile tilapia, Oreochromis niloticus (Linnaeus, 1758), originating in West and East Africa (Trewavas, 1983), is commercially the most important. It has been introduced into many Asian and South American countries. In Africa, several non-native populations are now established in many rivers, as in Côte d'Ivoire, where an aquacultural strain (resulting from the crossing of individuals from the Nile and Volta basins) is now present in all major rivers. Cameroon, Guinea and Benin also have some introduced populations which, as in Côte d'Ivoire, result

\footnotetext{
* $\ddagger$ Correspondence. E-mail: agnese@abidjan.orstom.ci
}

from the escape of farm stock. In many of these situations, it seems that this species did not cause the disappearance of any other species and, particularly, any related tilapia species. This was probably not the case in Lake Victoria where $O$. niloticus was introduced in the late 1950s (Kaufman, 1992). This species and also the Nile perch, Lates niloticus, another introduced species, are suspected of having played important roles in the disappearance of a closely related species, $O$. esculentus, which originally supported the lake's most important fishery (OgutuOhwayo, 1990).

The natural range of $O$. niloticus includes the Senegal, Gambia, Niger, Volta, Benue, Chari, Nile, and Awash Rivers and many lakes like those of the Rift Valley: Edward, George, Albert, Kivu, Tanganyika, Baringo, Turkana. Trewavas (1983) described seven subspecies, using morphometrical analysis: $O$. niloticus niloticus from West Africa and the Nile, $O$. 
n. eduardianus from Lakes George, Edward and Tanganyika, O. n. cancellatus from the Awash River system in Ethiopia, O. $n$. filoa from the hot springs of the Awash River, $O$. $n$. vulcani from Lake Turkana, $O . n$. baringoensis from Lake Baringo, and $O$. $n$. sugutae from the River Suguta in Kenya. Seyoum \& Kornfield (1992a) described a new subspecies, O. n. tana from Lake Tana in Ethiopia, using genetical (mitochondrial DNA) characteristics.

Even though $O$. niloticus has a wide distribution and a real economic importance, little is known about the genetic characterization of natural populations. This could be of great importance for the future development of aquacultural strains, for the protection of small endangered populations (like those of small lakes such as Baringo or the Suguta River), and for biogeographical inferences. The first genetic studies concerned the characterization of aquacultural strains (Basio \& Taniguchi, 1983; McAndrew \& Majumdar, 1983; Maracanas et al., 1995). Only recently have some studies been undertaken on natural populations: Seyoum \& Kornfield (1992a,b) reported a study of East African populations, Rognon (1993) and coworkers (1996) studied natural West African populations. The present study is then the first in which natural populations from the major basins (the Senegal, Niger, Volta, Nile, Awash and Suguta Rivers; Lakes Chad, Tana, Turkana, Edward, Baringo) and representing all the described subspecies are investigated using standardized techniques. This will allow the possibility of characterizing populations and subspecies and of making biogeographical inferences about the populations seen today.

\section{Materials and methods}

\section{Sampling and allozyme study}

Specimens of $O$. niloticus were collected from August 1993 to December 1994, in 17 locations (Fig. 1). They were kept at $-20^{\circ} \mathrm{C}$ for a few days and then maintained at $-80^{\circ} \mathrm{C}$ for later analysis, except for specimens from Lake Tana which were immediately preserved in alcohol. Specimens of $O$. aureus come from a farmed strain (Lake Manzalla, Egypt). Standard horizontal starch gel (12 per cent) electrophoresis was carried out to investigate the products of 25 loci. The stain recipes and buffer used were those described in Pasteur et al. (1987) and Pouyaud \& Agnèse (1995). The nomenclature is that proposed by Shaklee et al. (1990).

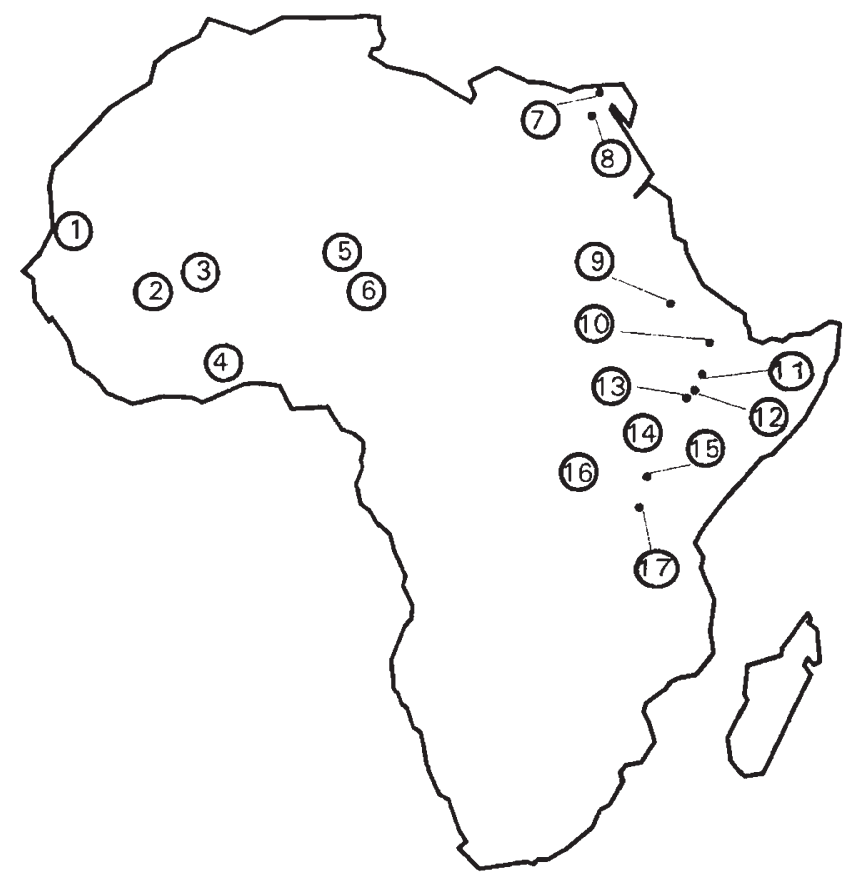

Fig. 1 Sampling locations for Oreochromis niloticus populations. 1, River Senegal at Dagana; 2, River Niger at Selingue; 3, River Niger at Bamako; 4, Lake Volta at Akosumbo; 5, Lake Chad near Karal; 6, River Chari at N'Jamena; 7, Lake Manzalla at Manzalla; 8, River Nile at Cairo; 9, Lake Tana at Bahar Dar; 10, hot springs of the Awash system at Sodore; 11, Lake Koka at Koka; 12, Lake Zyway at Meki; 13, Lake Awasa at Awasa; 14, Lake Turkana at Loyangalani; 15, River Suguta at Kapedo; 16, Lake Edward at Mweya; 17, Lake Baringo at Kampi ya Samaki.

\section{DNA extraction}

A piece of ethanol-preserved muscle $(0.1 \mathrm{~g})$ was dilacerated before being digested at $55^{\circ} \mathrm{C}$ for $24 \mathrm{~h}$ in $1 \mathrm{~mL}$ of $0.05 \mathrm{M}$ Tris $\mathrm{pH} 8.0,0.01 \mathrm{M}$ SDS, $0.01 \mathrm{M}$ EDTA containing $1 \mathrm{mg} \mathrm{mL}^{-1}$ proteinase $\mathrm{K}$. DNA was then extracted following a phenol-chloroform protocol.

\section{Amplification of the control region of mitochondrial DNA}

To amplify a $1 \mathrm{~kb}$ fragment in the control region of mtDNA, HN20 and LN20 primers (Bernatchez \& Danzmann, 1993) were used. The amplification conditions were as follow: $3 \mathrm{~mm} \mathrm{MgCl}_{2}, 0.5 \mathrm{~mm}$ of each nucleotide, $0.2 \mu \mathrm{M}$ of each primer, two units of Taq polymerase (Golstar Taq Polymerase from Eurogentec), $1 \times$ of Taq polymerase buffer and $5 \mu \mathrm{L}$ of DNA solution in a final volume of $50 \mu \mathrm{L}$. The 
amplification programme was: $96^{\circ} \mathrm{C}$ for $2 \mathrm{~min}, 93^{\circ} \mathrm{C}$ for $1 \mathrm{~min}, 55^{\circ} \mathrm{C}$ for $1 \mathrm{~min}, 72^{\circ} \mathrm{C}$ for $1 \mathrm{~min}$. The last three steps were repeated 30 times.

\section{Digestion of the amplified products}

Of the PCR-amplified control region, $5-8 \mu \mathrm{L}$ was digested by 5 units of one of the restriction enzymes in a final volume of $20 \mu \mathrm{L}$ containing the appropriate buffer. Digestions were carried out at $37^{\circ} \mathrm{C}$ overnight except for TaqI restriction enzyme, for which the temperature was $62^{\circ} \mathrm{C}$. The digestion products were separated and visualized in 2 per cent horizontal ethidium bromide stained $\mathrm{TBE}$ agarose gel.

\section{Analysis of the data}

To analyse allozymic or RFLP data, different programs from PHYLIP (PHYLIP software package, Felsenstein, v. 3.5) were used: CONSENSE, MIX, GENEDIST, NEIGHBOR, SEQBOOT

\section{Results}

\section{Allozymes}

Of the 25 loci studied, 16 were polymorphic (Table $1)$. The rate of observed heterozygosity $(H)$ was between 0.000 (Lake Baringo) and 0.045 (Volta River) and the rate of observed polymorphism ( $P 95$ per cent) between 0.00 (Lake Baringo) and 0.08 (all West African and Nile populations except the Niger River at Selingue). These values are comparable to those obtained in previous studies of natural $O$. niloticus populations (Seyoum \& Kornfield, 1992b; Rognon et al., 1996) even if the loci analysed were not the same as in the present study.

To build a genetic network, a total of 1000 randomly modified frequency matrices were obtained using the program SEQBOoT. These matrices were then transformed into Nei's (1972) genetic distance matrices using the GENEDIST program. The corresponding trees were built using the program NEIGHBOR and summarized into a single tree using CONSENSE (Fig. 2).

Populations are clustered in three major groups. One is composed of the Nile drainage (the Nile and Lake Edward), and the Kenyan Rift Valley populations (Lake Turkana, Lake Baringo and the Suguta River). The second major group is composed of the Ethiopian Rift Valley populations (Sodore and Lakes Koka, Awasa, Ziway) and the third group of the West African populations (the Senegal, Niger, Volta, Chari Rivers and Lake Chad).

\section{RFLP $m t D N A$}

Of the 14 enzymes examined in 36 specimens, five did not cleave the PCR mtDNA product $(P v u \mathrm{I}$, HindIII, CfoI, AvaI, ApaI), and three enzymes (AluI, EcoRV, NdeII) had iden"sal multibanded phenotypes among all subspec, s and $O$. aureus. Six enzymes gave 13 phenotypes (Table 2) corresponding to nine different haplotypes (Table 3).

In Sodore, Lake Edward and the Nile, more than one haplotype was found (two, two and four, respectively). Individuals from Suguta and Baringo have private haplotypes. On the contrary, Lake Chad and the Rivers Volta and Niger share the same haplotype, which is also present in the Nile population and in $O$. aureus. Specimens from Lakes Turkana, Edward and Tana also shared the same haplotype found in the Nile. Figure 3 shows the consensus tree calculated from the 18 most parsimonious networks obtained with the MIX program. The mtDNA haplotypes are geographically distributed. At one side of the network, all populations from West Africa and $O$. aureus are clustered (they share the same haplotype), on the other side there are the two Ethiopian Rift Valley populations and between these two groups are the Kenyan and Ugandan Rift Valley populations. The Nile population shows affinities with West African populations and with specimens from Lakes Tana and Turkana.

\section{Discussion}

\section{Taxonomy}

Rognon (1993) sequenced $270 \mathrm{bp}$ of the cytochrome b gene in $O$. aureus from the Nile (Lake Manzalla) and $O$. niloticus from West Africa (the Senegal, Niger and Volta Rivers) and the Nile (Lake Manzalla). The results showed that West African $O$. niloticus mtDNA was closer to $O$. aureus mtDNA than to the single haplotype observed in three individuals from the Nile population. Two hypotheses may explain why $O$. aureus and $O$. niloticus can share the same mtDNA. First, this haplotype may be an ancestral one which existed before the two species were isolated. Secondly, the mtDNA of one species could have been established in the other without nuclear contamination. This phenomenon has already been observed in fishes (Duvernell \& Aspinwall, 1995). Tilapia species are well known for their ability to hybridize in captivity (Crapon de Crapona \& Fritzsch, 1984), in the case of introduced species (Daget \& Moreau, 1981; Elder et al., 1971), or in natural conditions (Pouyaud, 1994). Trewavas (1983) reported some experiments of hybridization between 
POPULATION GENETICS OF NILE TILAPIA

91

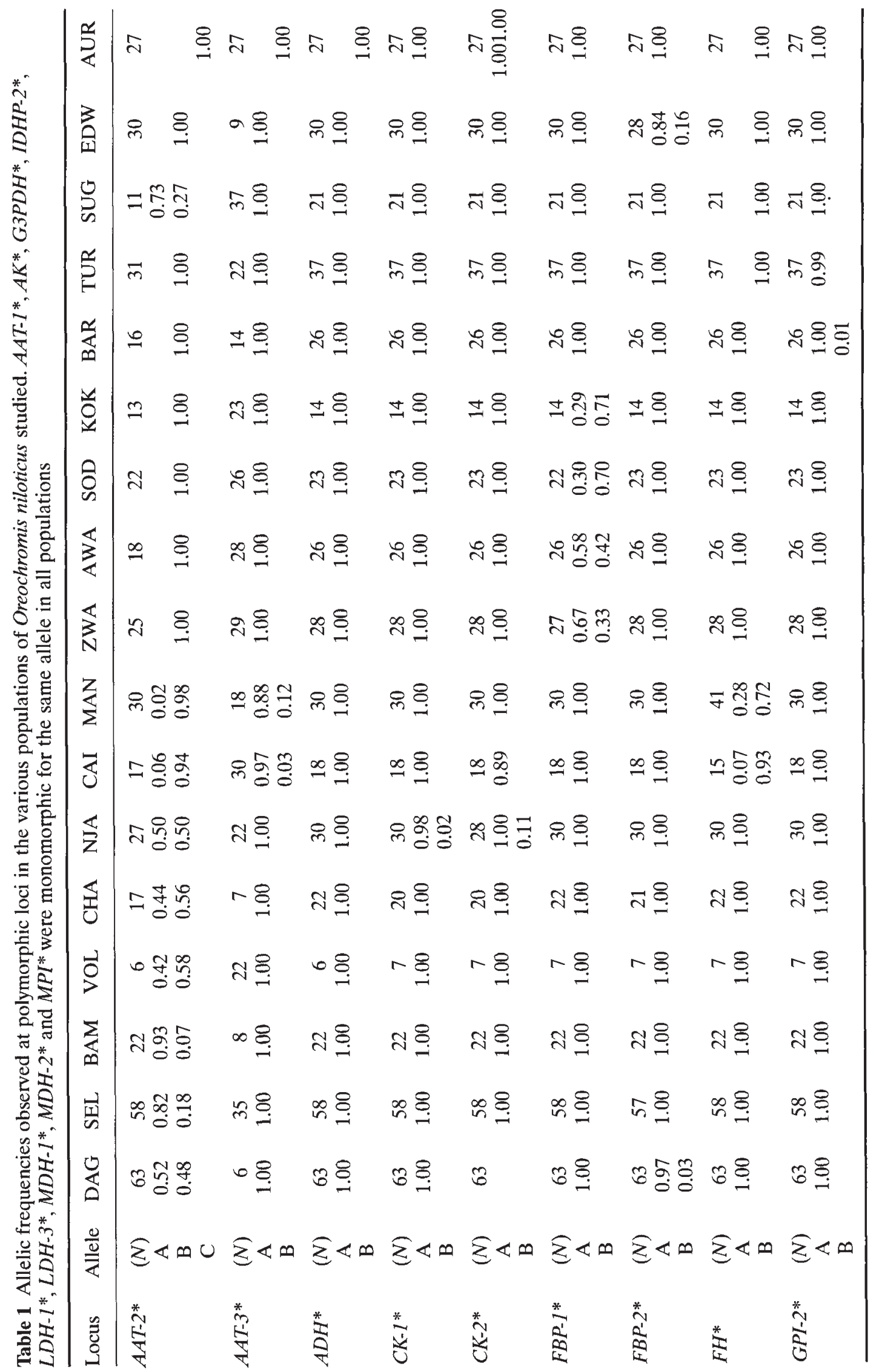

(c) The Genetical Society of Great Britain, Heredity, 79, 88-96. 


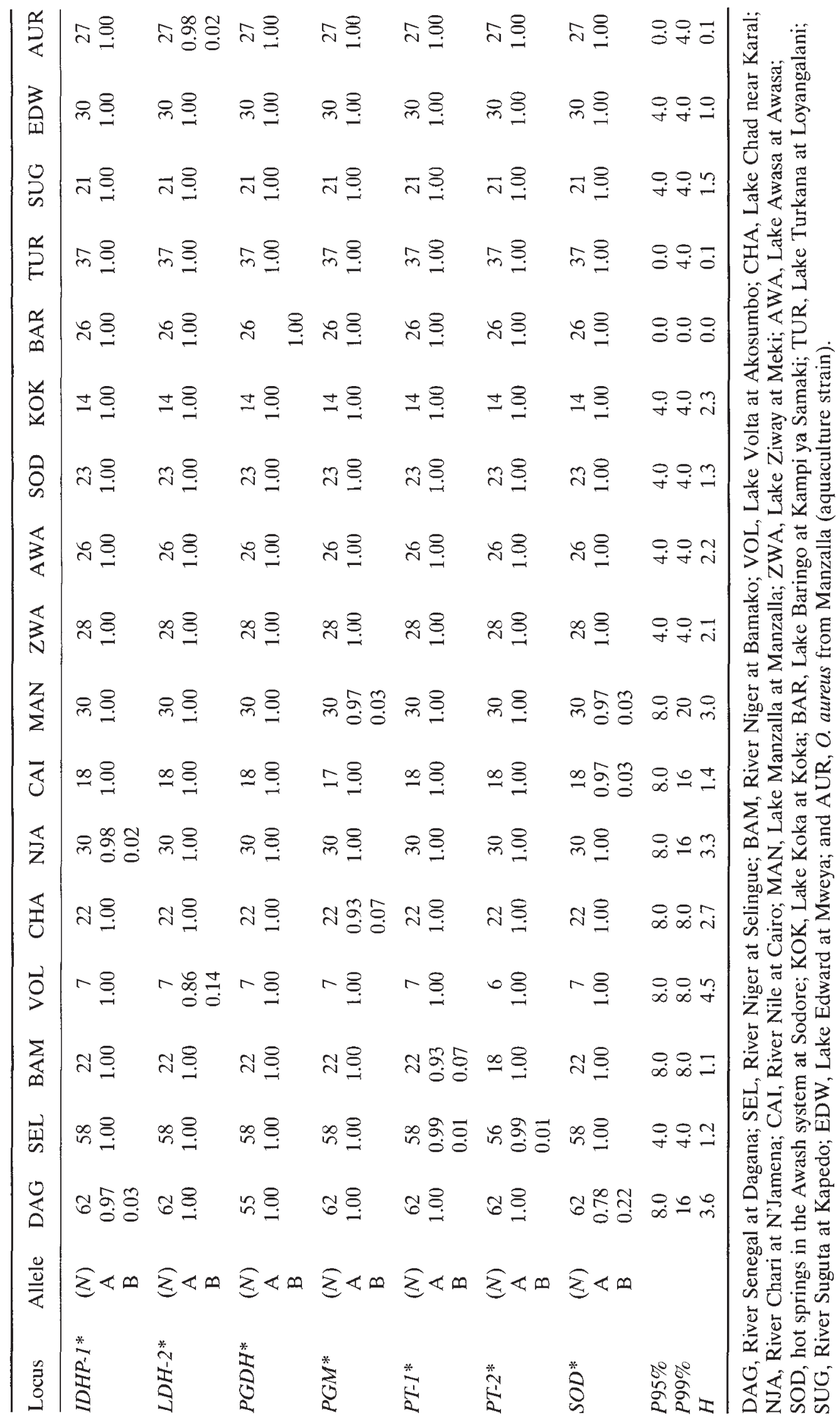




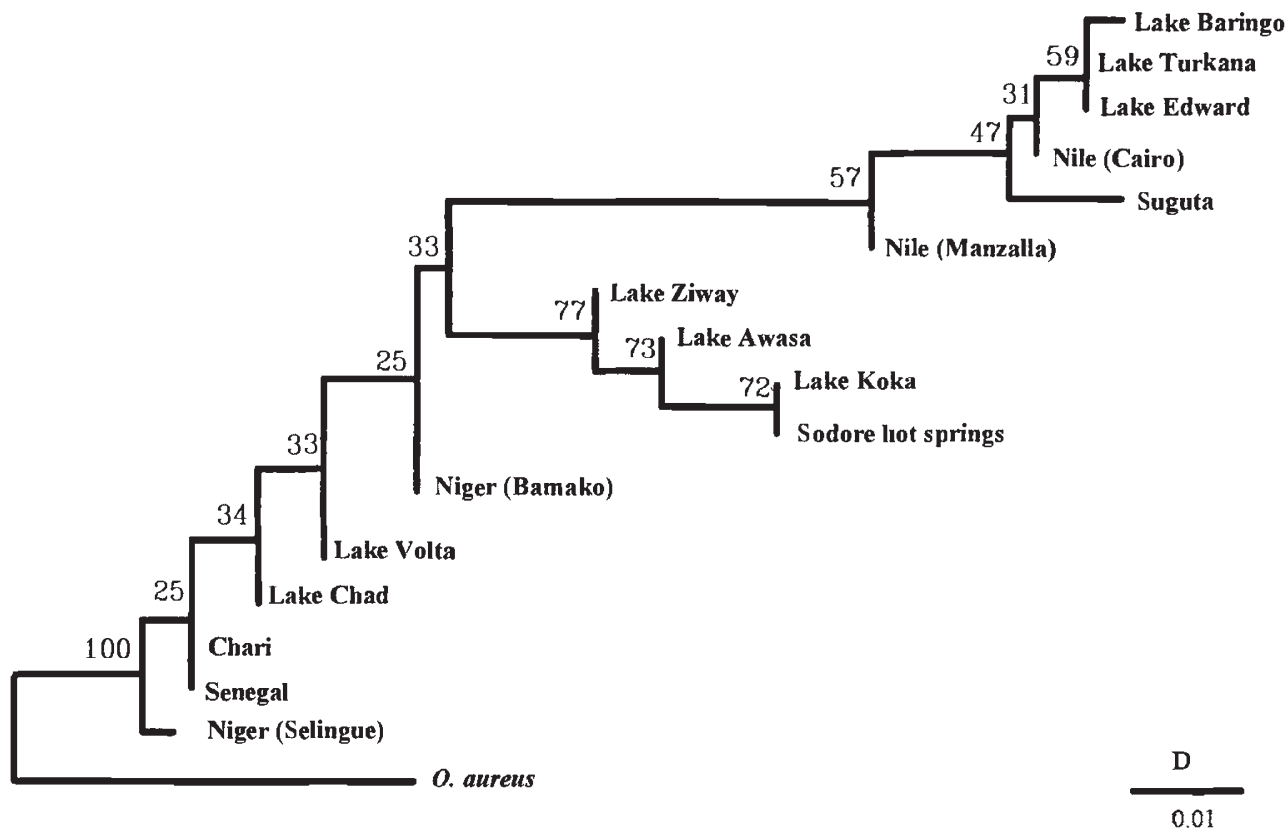

Fig. 2 Network produced by PHYLIP on the 16 populations representing seven subspecies of Oreochromis niloticus. This is a consensus tree produced using CONSENSE from 1000 trees produced using SEOBOOT and NEIGHBOR. The number at each junction represents the frequency of its occurrence.

Table 2 Fragments produced by restriction enzyme digestions of amplified Oreochromis niloticus and $O$. aureus mtDNA D-loop region. The asterisk denotes two fragments with equal molecular size which were visualized as an extra-intense band on the gels

\begin{tabular}{|c|c|c|c|c|c|c|c|c|c|c|c|c|c|}
\hline \multirow{2}{*}{$\begin{array}{l}\text { Enzyme } \\
\text { Haplotypes }\end{array}$} & \multicolumn{2}{|c|}{ AsnI } & \multicolumn{3}{|c|}{ HinfI } & \multicolumn{2}{|c|}{ RsaI } & \multicolumn{2}{|c|}{ AvaII } & \multicolumn{2}{|c|}{ MspI } & \multicolumn{2}{|c|}{$T a q \mathrm{I}$} \\
\hline & A & B & A & B & $\mathrm{C}$ & A & B & A & B & A & B & A & B \\
\hline & 1000 & 680 & 660 & 400 & 440 & 710 & 710 & 1000 & 550 & 820 & 520 & 700 & 520 \\
\hline & & 320 & 320 & $290^{*}$ & $\begin{array}{l}320 \\
220\end{array}$ & 290 & 260 & & 450 & 180 & $\begin{array}{l}300 \\
180\end{array}$ & 300 & 480 \\
\hline
\end{tabular}

$O$. aureus and $O$. niloticus. The crosses $O$. aureus male with $O$. niloticus female and vice versa, gave a high proportion of males (90-100 per cent). In these conditions, transfer of a mtDNA haplotype from one species to the other by natural hybridization is difficult. Another observation seems to favour the ancestral DNA hypothesis. Rognon (1993) sequenced mtDNA (cytochrome b) from many Oreochromis and Sarotherodon species, two genera which are very close (Pouyaud \& Agnèse, 1995). This author observed that some haplotypes of Sarotherodon galilaeus are closer to some $O$. aureus and $O$. niloticus haplotypes (4-6 substitutions) than they were to some haplotypes of $O$. macrochir or $O$. hornorum (20-23 substitutions). It seems likely therefore that $S$. galilaeus, $O$. aureus and $O$. niloticus share a common ancestral mtDNA haplotype.
The results obtained by Seyoum \& Kornfield (1992a,b), with total mtDNA digestions suggested that $O$. n. cancellatus and $O$. $n$. filoa form a group independent of all other subspecies. The population of $O$. $n$. tana also showed, in these studies, a large divergence from other populations. Accordingly, they decided to consider $O$. $n$. cancellatus and $O$. $n$. filoa as a new taxon with two subspecies: $O$. cancellatus cancellatus and $O$. c. filoa, respectively. The Population from Lake Tana was then considered as a new subspecies, $O$. n. tana. Our results suggest that the taxonomic ranks given by Seyoum \& Kornfield (1992a,b) may be a little premature. In the allozyme study, populations from the Ethiopian Rift Valley, Lakes Ziway and Koka, and the Awash River for $O$. $n$. cancellatus and Sodore for $O$. $n$. filoa, did not form a strongly independent group. They are related 
Table $3 \mathrm{mtDNA}$ haplotypes observed in 36 specimens of Oreochromis niloticus and $O$. aureus

\begin{tabular}{lllll}
\hline & Haplotype & Population & Subspecies & $N$ \\
\hline 1 & ACABBB & Suguta & O. n. sugutae & 3 \\
2 & BAABBB & Lake Baringo & O. n. baringoensis & 3 \\
3 & AAABBB & Lake Edward & O. n. eduardianus & 2 \\
& & Nile (Manzalla) & O. $n$. niloticus & 2 \\
& & Lake Tana & O. n. cancellatus & 3 \\
4 & AAABAB & Lake Edward & O. n. eduardianus & 1 \\
5 & BAABAB & Lake Ziway & O. n. cancellatus & 3 \\
& & Sodore hot springs & O. n. floa & 2 \\
6 & BAABAA & Sodore hot springs & O. n. filoa & 1 \\
7 & ABBAAA & Nile (Manzalla) & O. n. niloticus & 1 \\
& & Lake Volta & O. n. niloticus & 3 \\
& & Lake Chad & O. n. niloticus & 4 \\
& & Niger (Selingue) & O. n. niloticus & 3 \\
& & O. aureus & & 3 \\
9 & AABBBB & Nile (Manzalla) & O. n. niloticus & 1 \\
AABABB & Nile (Manzalla) & O. n. niloticus & 1 \\
\hline
\end{tabular}

$N$, number of specimen studied.

to other populations of the $O$. n. niloticus subspecies. In the mtDNA RFLP study, a similar pattern was observed and did not share the high level of differentiation suggested by Seyoum \& Kornfield's (1992a) results: O. n. cancellatus and O. n. filoa share the same haplotype which is close to that observed in Lake Baringo ( $O$. niloticus baringoensis). If we consider the haplotype shared by $O$. aureus and $O$. $n$. niloticus as an ancestral one, then the Ethiopian Rift Valley haplotypes can be considered as derived in contrast to Seyoum \& Kornfield's 1992a results. The differences in the results between these two studies may be attributable to the different techniques employed. In the present study, we digested a $1 \mathrm{~kb}$ fragment instead of the $17 \mathrm{~kb}$ (the total mtDNA) used by Seyoum \& Kornfield $(1992 a, b)$. In these conditions, the number of restriction sites observed is far less important but the quality of the information from the fragments is better. On the one hand, if we summarize the total length of DNA observed when Seyoum \& Kornfield (1992a,b) made digestions of mtDNA of $O$. niloticus from Lake Tana with RsaI and MboII, 15681 and $17335 \mathrm{bp}$ were observed, respectively. If, on the other we consider all seven different haplotypes they found with RsaI, they range from 15681 bp (haplotype E) to 1721.9 bp (haplotype F). The differences observed may be caused not only by the difficulty in observing small fragments (less than $50 \mathrm{bp}$, for example) but also in assessing the size of each fragment. In the present study, with HinfI and RsaI, the total length of the different strands observed is

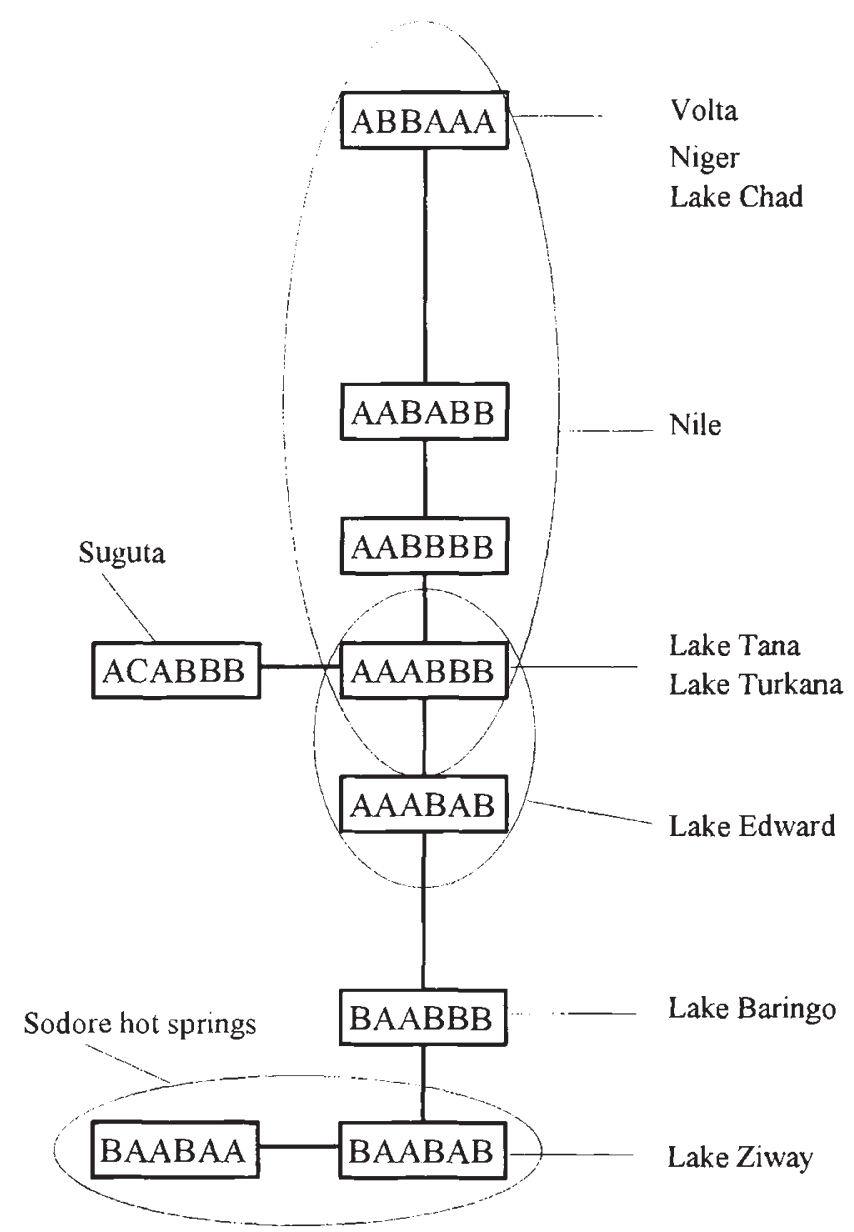

Fig. 3 Network produced by PHYLIP on the nine mtDNA haplotypes observed for Oreochromis. This is a consensus tree, produced using CONSENSE, from the 18 most parsimonious trees produced using MIX.

sometimes different from the amplification product length. This is attributable to small fragments $(20$ or $30 \mathrm{bp}$ ), which cannot be seen with our technique. In our case, as we consider the different haplotypes instead of the presence or absence of the different fragments, this has no consequence on the treatment of the RFLP data. Another difference between this study and that of Seyoum \& Kornfeld (1992a,b) is that although they observed more restriction sites, they did not observe any intrapopulation polymorphism. In the present study, the five specimens investigated in the Nile population have four different haplotypes. Sodore and Lake Edward populations (three specimens investigated) are also polymorphic. For all these reasons, the conclusions of Seyoum \& Kornfield (1992a,b) have to be considered with caution. However, and regardless of the network's robustness, taxonomic decisions based on mtDNA phylogenies are problematic. If the ances- 
tral species or population was polymorphic in its mtDNA, the haplotypes of the new species or populations might accurately reveal the order in which the haplotypes originated within the ancestor, but this order may differ from the order in which species or populations appeared. In the present study, the Nile population seems to be highly polymorphic (five specimens studied and four haplotypes observed) and we can assume that the ancestral population could be as polymorphic as this one.

There are some differences observed between our results and Trewavas' (1983) nomenclature. Trewavas (1983) assigned the population from Lake Tana to $O$. $n$. cancellatus, not on a firm morphological basis but because the non-cichlid fishes of Lake Tana were all assigned to Ethiopian species (Seyoum \& Kornfield, 1992a). In our study, the Lake Tana mtDNA haplotype is similar to one observed in the Nile population and different from the one observed in the Ethiopian populations. Microsatellite studies (L. Pouyaud, pers. comm.) confirm that this population is closely related to the Nile population. These results could allow modification of the subspecific status of this population $(O$. $n$. niloticus instead of $O . n$. cancellatus). Another difference between our results and Trewavas' (1983) nomenclature is the genetic differentiation observed in $O$. n. niloticus. All West African populations (Senegal, Niger, Volta, Chad basins) are closely related, whereas populations from the Nile are closer to East African populations (Lakes Edward, Turkana, Baringo and River Suguta). Morphological differentiation, on which the subspecific nomenclature is based, is then different from the genetic differentiation. From the genetic point of view, natural populations of $O$. niloticus are clustered in three groups: (i) the West African populations (Senegal, Niger, Volta, Chad drainages); (ii) the Ethiopian Rift Valley populations (Lakes Ziway, Awasa, Koka and Sodore hot springs in the Awash River); (iii) the Nile drainage populations (Nile, Lakes Tana, Edward) and the Kenyan Rift Valley populations (Lakes Turkana, Baringo and River Suguta).

\section{Biogeography}

The distribution of species or populations and their genetic structure depends not only on biological and environmental but also on historical factors. In fact, it is difficult to explain the spatial distribution of populations forming one species without taking into account these factors. From the Pleistocene to the present time, Africa has experienced alternating dry and humid climatic phases which have had a profound influence on expansion and regression of populations as well as speciation (Haffer, 1982; Livingstone, 1982). These climatic changes (Maley, 1991) could explain the genetic structure of some fish populations in West Africa (Agnèse, 1989; Adépo-Gourène et al., 1997). In East Africa, many tectonic movements and much volcanic activity have had a major role in the formation of the different basins and then in the distribution of fish species (Fryer \& Iles, 1972; Trewavas, 1983).

With our results, it is possible to recreate some of the past events that have contributed to the current distribution of $O$. niloticus populations. Colonization events come with bottleneck effects because of the generally small size of populations that go from one basin to another. These bottlenecks strengthen the genetic drift and then lead to the loss of genetic diversity. In these conditions, populations located at, or close to, the origin of the species are those that should have the higher values of genetic diversity. If we consider the level of polymorphism, $P$ (Table 1 ), populations can be divided into two groups: on one hand the Nile and West African populations (subspecies $O$. $n$. niloticus) with $P$-values never less than 0.08 , on the other hand, the East African populations (all other subspecies) with $P$-values never greater than 0.04 . The number of mtDNA haplotypes also varies between the populations. Although the number of specimens studied in each population was small (3-5), the Nile population can be considered as the more polymorphic (five specimens and four haplotypes). These observations lead us to hypothesize that the origin of $O$. niloticus could be the Nile. From this area, individuals have been able to colonize, independently, East and West Africa. To expand further into the elaboration of a colonization model, more data on the genetic differentiation of the populations are necessary. The study of the mtDNA of a greater number of specimens of each population would allow the more precise evaluation of the importance of intrapopulational polymorphism. The use of other techniques such as microsatellites seems very promising (L. Pouyaud, personal communication). Already, multilocus fingerprinting and RAPD (Bardakci \& Skibinski, 1994; Naish et al., 1995) have shown themselves to be very interesting for the genetic characterization of populations of $O$. niloticus.

\section{Acknowledgements}

This work was supported by the European Community (contract no. ERBTS3*CT920079) and 
ORSTOM (L'Institut Français de Recherche pour le Développement en Coopération). The authors wish to thank Mrs S. Gilles, R. Berthonnet, J. Lemoalle. O. Mikolasek, A. Pariselle, L. Pouyaud, J. C. Thouvenel, J. L. Zeddam, P. Golbutsov and W. Dimmick for their valuable help in collection of material.

\section{References}

AdÉPo-gourène, B., TEUgels, G., RisCh, M., hANSSENS, M., AND AGNĖSE, J.-F. 1997. Morphological and genetical differentiation of eleven populations of the African Catfish Chrysichthys nigrodigitatus (Siluroidei; Claroteidae) with a consideration of their biogeography. Can. J. Zool., 75, 102-109.

AGNÈsE, J.-F. 1989. Différenciation génétique de plusieurs espèces de Siluriformes Ouest-Africains ayant un intérêt pour l'aquaculture. PhD Thesis, University of Montpellier, France.

BARDAKCI, F. AND SKIBINSKI, D. O. F. 1994. Application of the RAPD technique in tilapia fish: species and subspecies identification. Heredity, 73, 117-123.

BASIO, Z. U. AND TANIGUCHI, N. 1983. An investigation of enzyme and other protein polymorphism in Japanese stocks of the tilapias Oreochromis niloticus and Tilapia zillii. Aquaculture, 38, 335-345.

BERNATCHEZ, L. AND DANZMANN, R. G. 1993. Congruence in control-region sequence and restriction-site variation in mitochondrial DNA of Brook Charr (Salvelinus fontinalis Mitchill). Mol. Biol. Evol., 10, 1002-1014.

CRAPON DE CRAPONA, M. D. AND FRITZSCH, B. 1984.Interspecific fertile hybrids of haplochromine Cichlidae (Teleostei) and their possible importance for speciation. Neth. J. Zool, , 34, 503-538.

DAGET, I. AND MOREAU, J. 1981. Hybridation introgressive entre deux espèces de Sarotherodon (Pisces, Cichlidae) dans un lac de Madagascar. Bull. Mus. natn. Hist. Nat., $4^{e}$ sér., 3 section A, no. 2, 689-703.

DUVERNELL, D. D., AND ASPINWALL, N. 1995. Introgression of Luxilus cornutus mtDNA into allopatric populations of Luxilus chrysocephalus (Teleostei: Cyprinidae) in Missouri and Arkansas. Mol. Ecol., 4, 173-181.

ELDER, H. Y., GARROD, D. J. AND WHITEHEAD, P. J. P. 1971. Natural hybrids of the African Cichlid fishes Tilapia spilurus and T. leucosticta: a case of hybrid introgression. Biol. J. Linn. Soc., 3, 103-146.

FRYER, G. AND ILES, T. D. 1972. The Cichlid Fishes of the Great Lakes of Africa: Their Biology and Evolution. Oliver and Boyd, Edinburgh.

HAFFER, .t. 1982. General aspects of the refuge theory. In: Prance, G. T. (ed.) Biological Diversification in the Tropics. pp. 6-24. Columbia University Press, New York.

KAUFMAN, L. 1992. Catastrophic change in species-rich freshwater ecosystems. The lessons of Lake Victoria. Bioscience, 42, 846-858.

Livingstone, D. A. 1982. Quaternary geography of Africa and the refuge theory. In: Prance, G. T. (ed.) Biological
Diversification in the Tropics, pp. 523-536. Columbia University Press, New York.

MALEY, J. 1991. The African rain forest vegetation and paleoenvironments during late quaternary. Clim. Change, 19, 79-98.

maracanas, J. M., Agustin, L. O., ABLAN, C. K., PANTE, J. R., EKNATH, A. A. AND PULlin, R. s. V. 1995. Genetic improvement of farmed tilapias: biochemical characterization of strain differences in Nile tilapia. Aquaculture International, 3, 43-54.

McANDREW, B. J. AND MAJUMDAR, K. C. 1983. Tilapia stock identification using electrophoretic markers. Aquaculture, 30, 249-261.

NAISH, K. A., WARREN, M., BARDAKCI, F., SKIBINSKI, D. O. F., CARVAlHo, G. R. AND MAIR, G. C. 1995. Multilocus DNA fingerprinting and RAPD reveal similar genetic relationships between strains of Oreochromis niloticus (Pisces: Cichlidae). Mol. Ecol., 4, 271-274.

NEI, M. 1972. Genetic distances between populations. Am. Nat., 106, 283-292.

OGUTU-OHWAYO, R. 1990. The decline of the native fishes of lakes Victoria and Kyoga (East Africa) and the impact of introduced species, especially the Nile perch, Lates niloticus, and the Nile tilapia, Oreochromis niloticus. Environ. Biol. Fish., 27, 81-96.

PASTeur, N., PASTeur, G., BONHOMME, F., CATALAN, J. AND BRITTON-DAVIDIAN, J. 1987. Practical Isosyme Genetics. Hellis Horwood Ltd, Chichester, UK.

pouyaud, L. 1994. Génétique des populations de tilapias d'intérêt aquacole en Afrique de l'Ouest. Relations phylogénétiques et structuration populationnelles. $\mathrm{PhD}$ Thesis, University of Montpellier II, France.

POUYAud, L. AND AGNĖSE, J.-F. 1995. Phylogenetic relationships between 21 species of three tilapiine genera Tilapia, Sarotherodon and Oreochromis using allozyme data. J. Fish Biol., 47, 26-38.

ROGNON, X. 1993. Diversité génétique et relations phylogénétiques chez les tilapias (Pisces, Cichlidae). Comparaison des données du polymorphisme enzymatique et mitochondrial. PhD Thesis, University of Paris-Sud Orsay, France.

ROGNON, X., ANDRIAMANGA, M., MCANDREW, B. AND GUYOMARD, R. 1996. Allozyme variation in natural and cultured populations in two Tilapia species: Oreochromis niloticus and Tilapia zillii. Heredity, 76, 640-650.

SEYOUM, S. AND KORNFIELD, I. 1992a. Taxonomic notes on the Oreochromis niloticus subspecies-complex (Pisces: Cichlidae), with a description of a new subspecies. Can. J. Zool., 70, 2161-2165.

SEYOUM, S. AND KORNFIELD, I. 1992b. Identification of the subspecies of Oreochromis niloticus (Pisces: Cichlidae) using restriction endonuclease analysis of mitochondrial DNA. Aquaculture, 102, 29-42.

SHAKLEE, J. B., ALLENDORF, F. W., MORIZOT, D. C. AND WHITT, G. S. 1990. Gene nomenclature for protein coding loci in fish. Trans. Am. Fish. Soc., 119, 2-15.

Trewavas, E. 1983. Tilapiine Fishes of the Genera Sarotherodon, Oreochromis and Danakilia. British Museum (Natural History), London. 